\title{
The Yoron Hole: The Shallowest Hydrothermal System in the Okinawa Trough
}

\author{
Tatsuhiro Fukuba, Takuroh Noguchi, and Teruo Fujii
}

\begin{abstract}
During NT10-16 cruise with R/V NATSUSHIMA and ROV HYPER-DOLPHIN in 2010, a new hydrothermal vent community was discovered at the Yoron Hole, where is the shallowest hydrothermal system in the known hydrothermal site found in the Okinawa Trough. The maximum temperature of clear smoker fluid was $247^{\circ} \mathrm{C}$, which was slightly lower than the boiling temperature $\left(275^{\circ} \mathrm{C}\right)$ of the seawater at the water pressure of $560-\mathrm{m}$ water depth (5.6 MPa). Hydrothermal chimneys are composed of barite, sphalerite, galena, pyrite, chalcopyrite, and tetrahedrite. Although crustaceans and polychaetes were found around the hydrothermal vent, the diversity and population density were lower than that of the Iheya North Knoll and the Izena Hole hydrothermal sites.
\end{abstract}

\section{Keywords}

Chemosynthetic ecosystem $•$ Hydrothermal site survey $\bullet$ The Yoron Hole

\subsection{Location and Geological Settings}

The Yoron Hole locates in the adjacent seamount to the wellstudied deep-sea hydrothermal systems such as the Iheya Ridge, the Iheya North Knoll, and the Izena Hole, in the northwest region of the Okinawa Island, and was formed by arc-backarc volcanisms in the Okinawa Trough (Fig. 38.1, left). The seamount of the Yoron Hole has approximately $500 \mathrm{~m}$ of the relative height and it has a clearly recognizable crater at the north flank of the seamount (Fig. 38.1, right). Diameter of the crater has area of $3 \mathrm{~km}$ east to west and $2 \mathrm{~km}$

The online version of this chapter (doi:10.1007/978-4-431-54865-2_38) contains supplementary material, which is available to authorized users.

T. Fukuba $(\bowtie) \bullet$ T. Noguchi

Marine Technology and Engineering Center,

Japan Agency for Marine-Earth Science and Technology,

2-15 Natsushima-cho, Yokosuka, Kanagawa 237-0061, Japan

e-mail: bafuk@jamstec.go.jp

\section{T. Fujii}

Institute of Industrial Science, The University of Tokyo,

4-6-1 Komaba, Meguro-ku, Tokyo 153-8505, Japan north to south, and relative depth is approximately $350 \mathrm{~m}$. Hydrothermal vents are localized on the northeast slope of the crater.

\subsection{Survey History}

The Yoron Hole was firstly discovered by underwater topographic survey operations of Japan Coast Guard during a series of cruises from July 2008 to march 2009, and reported as an underwater volcanic crater (Horisako et al. 2010). Detailed scientific survey on hydrothermal activity of the Yoron Hole was intensively performed by a joint research group of the University of Tokyo, Kochi University, Central Research Institute of Electric Power Industry (CRIEPI), and Japan Agency for Marine-Earth Science and Technology (JAMSTEC) using R/V NATSUSHIMA and ROV HYPER-DOLPHIN (JAMSTEC) during NT10-16 cruise in 2010 (Fukuba 2010). In NT10-16, physicochemical anomaly caused by the hydrothermal plume was detected with in situ chemical sensors, and the shallowest hydrothermal site in the Okinawa Trough was discovered at the northeastern slope of the crater. The following scientific cruises have 


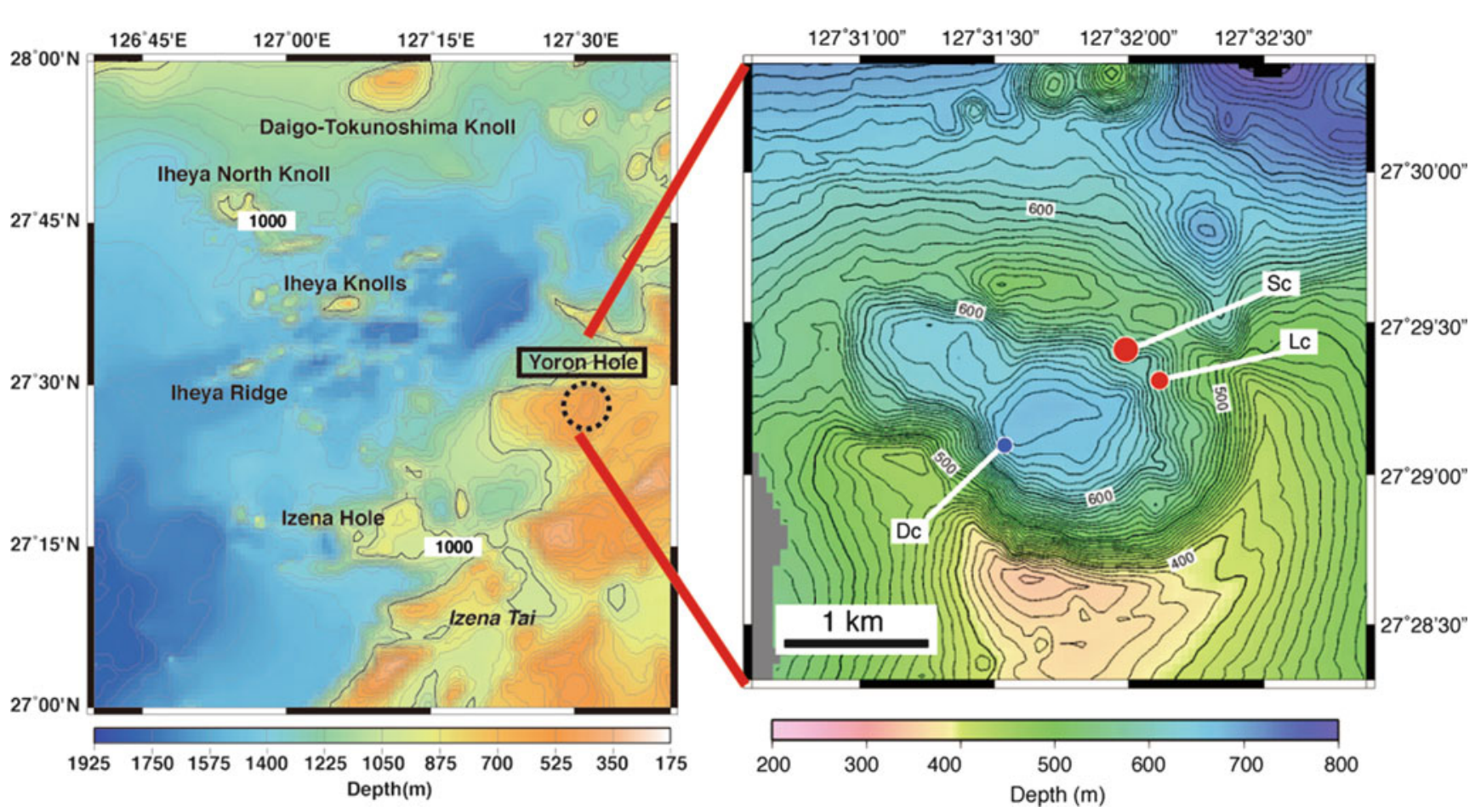

Fig. 38.1 Bathymetric map of the Mid-Okinawa Trough and location of hydrothermal vents at the Yoron Hole. $S c$ hydrothermal vent with small chimneys, $L c$ the largest chimney and simmering, $D c$ dead chimneys

conducted for other hydrothermal vent survey and biogeochemical studies (e.g. NT11-17 and NT11-20 using R/V NATSUSHIMA and ROV HYPER-DOLPHIN) (Fukuba 2011; Ishibashi 2011). The area including the Yoron Hole and the surrounding volcanic topographies was provisionally named as the North-East (NE) Izena or the Yoron Knoll. The formal name, the Yoron Hole, was inscribed in the IHOIOC GEBCO Gazetteers of Undersea Feature Names in 2012 (General Bathymetric Chart of the Ocean 2012).

\subsection{Hydrothermal Activity and Biogeochemical Properties}

The anomalies of seawater temperature, $\mathrm{pH}, \mathrm{pCO}_{2}, \mathrm{ORP}$, and Mn concentration detected by in situ sensor observation (Provin et al. 2013) had focal points on the east to the northeast slope of the hole at depth of 500-600 m. The observation according to the detail camera survey in the anomaly area, multiple hydrothermal vents were recognized around a gorge on the northeast slope in the hole, and their water depth were ranged between 560 to $590 \mathrm{~m}$ (Fig. 38.2a, b). There are some small clear smoker chimneys $(10-30 \mathrm{~cm}$ tall) at the north slope of the gorge, and measured maximum hydrothermal fluid temperature was $247{ }^{\circ} \mathrm{C}$. In the south slope of the gorge, there is a large active chimney gushing clear hydrothermal fluid whose maximum temperature was $85^{\circ} \mathrm{C}$ (Suppl. 38.1a). Around the large chimney, there are some white colored hydrothermally altered area with shimmering fluid (maximum temperature of $121{ }^{\circ} \mathrm{C}$ ) (Suppl. 38.1b). Dead chimneys (Suppl. 38.1c) were discovered on the bottom of the southwestern slope of the hole. Active hydrothermal vents were discovered in a limited area on northeastern slope of the hole, therefore, it seems to be the center of a hydrothermal discharge zone in the Yoron Hole.

Although chemosynthetic ecosystems formed around the active hydrothermal vents, the population density and diversity were scant in comparison to fauna of the Iheya Knoll or the Izena Hole. Small numbers of crustacean are living around the active vents (Fig. 38.2c, d). Alvinelid polychaeta formed patchy colonies on the foot part of the active chimneys (Fig. 38.2e). Surface of the chimneys had partially covered with yellowish-white filamentous mats, probably be made from bacteria (Fig. 38.2f).

Major geological features in the Yoron Hole are shown in Suppl. 38.1d,e. Surface of the slope was composed of volcanic detritus, and partially covered by thin sediment. The center of the hole was flat plain covered by sandy sediment. The analysis on geological features of rocks, massive sulfides, and chimneys are undergoing yet (Fujiwara et al. 2013; Takamasa et al. 2013). Preliminary result for mineral composition of the hydrothermal chimneys shows that barite is a dominant mineral and sphalerite, galena, pyrite, chalcopyrite, and tetrahedrite are included as minor contents. Ishibashi et al. (2013) suggested that the arsenic and silver contents in the tetrahedrite are slightly higher than those in 
Fig. 38.2 Digital camera images of hydrothermal vents and surrounding biological communities (NT10-16 cruise, 2010). (a) and (b): Small active chimneys emitting clear fluid, (c-f): Biological members observed in the Yoron Hole. (c) Munidopsis sp. and a xanthid crab, (d) Alvinocaridid shrimps, (e) Alvinelid polychaetes, and (f) Filamentous bacteria mat a

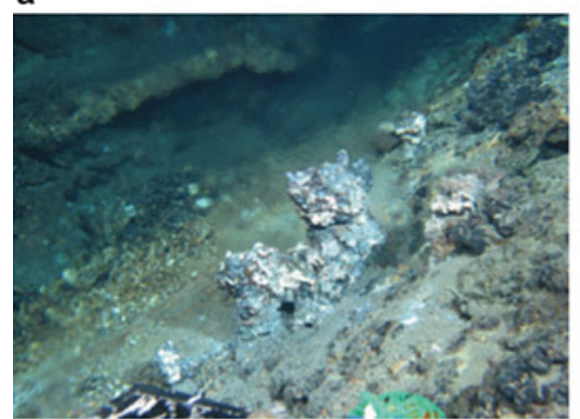

C

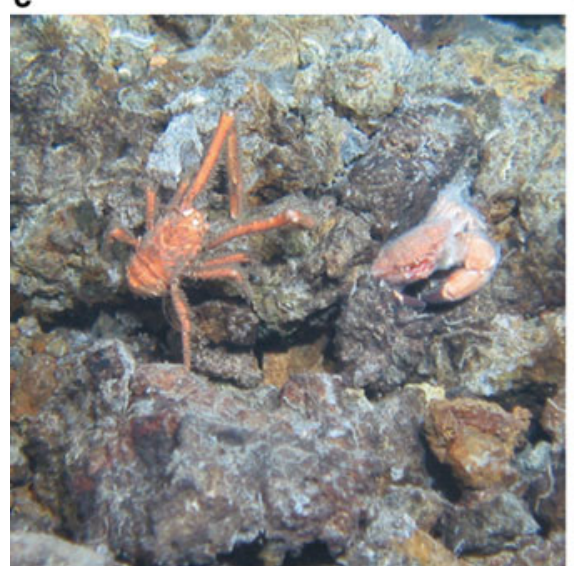

e

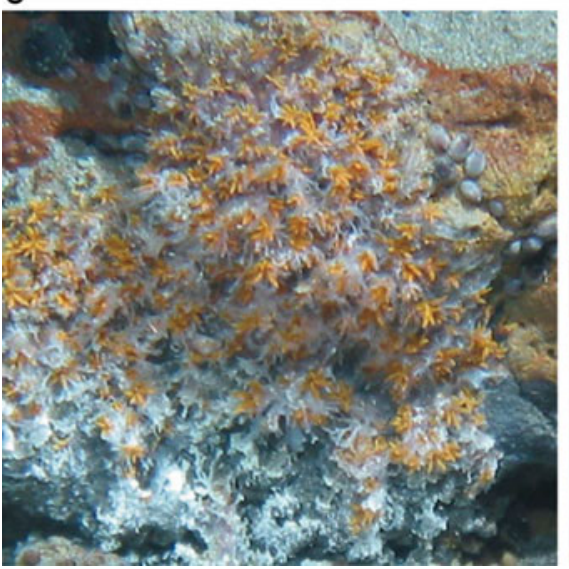

b

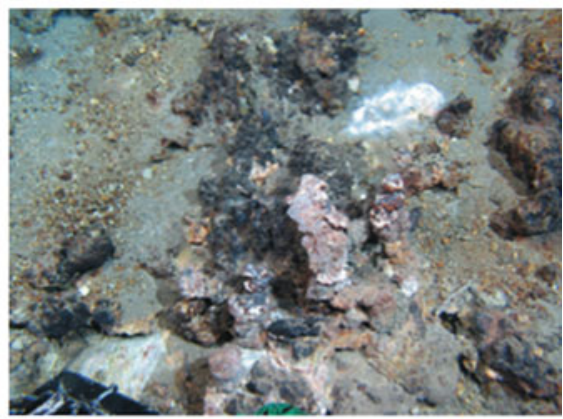

d

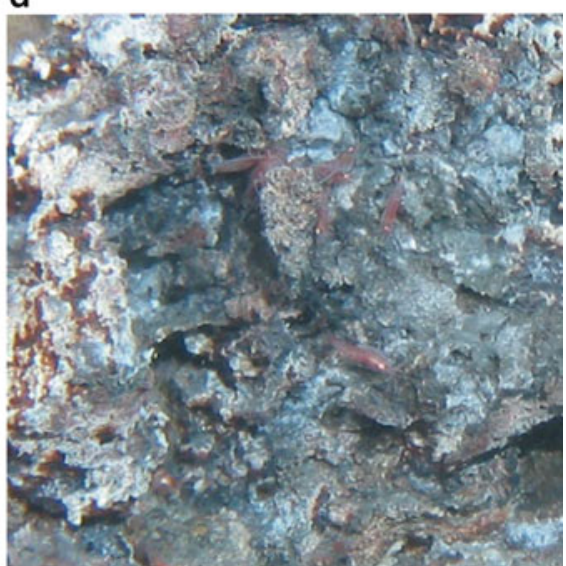
f

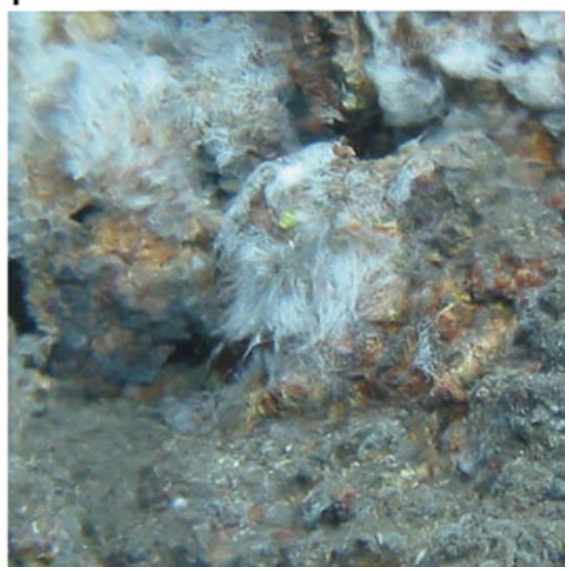

tetrahedrite samples from the other hydrothermal field in the Okinawa Trough, which might be reflected by geophysical parameters (e.g. temperature, $\mathrm{pH}$, water depth, etc.).

Acknowledgement Part of the bathymetric data was supplied from Japan Oceanographic Data Center (JODC). This work was partially supported by a Grant-in-Aid for Scientific Research on Innovative Areas (Project TAIGA, no. 20109003).

Open Access This chapter is distributed under the terms of the Creative Commons Attribution Noncommercial License, which permits any noncommercial use, distribution, and reproduction in any medium, provided the original author(s) and source are credited.

\section{References}

Fujiwara T, Toyoda S, Ishibashi J, Nakai S, Uchida A, Takamasa A (2013) ESR dating of barite in sea-floor hydrothermal sulfide deposits. In: Proceedings of Japan Geoscience Union Meeting 2013 (May 19-24, 2013, Chiba, Japan), SGL40-P07

Fukuba T (2010) A study on novel hydrothermal ore mine survey by in situ multi parameter measurement, Cruise report of NT10-16. http://www. godac.jamstec.go.jp/darwin/cruise/NATSUSHIMA/nt10-16/e

Fukuba T (2011) A study on a hydrothermal plume mapping and a novel hydrothermal ore mine survey by in situ multi parameter measurements, Cruise report of NT11-17. http://www.godac. jamstec.go.jp/darwin/cruise/NATSUSHIMA/nt11-17/e 
General Bathymetric Chart of The Ocean (2012) 25th GEBCO SubCommittee on Undersea Feature Names (SCUFN) Meeting Report, New Zealand, pp 23-27, Oct 2012. http://www.gebco.net/data_and_ products/undersea_feature_names/documents/gebco_scufn25.pdf

Horisako J, Dojun S, Tanaka K, Otonari Y, Hashimoto T (2010) Preliminary report of the bathymetric survey in the region to the northwest of Okinawa Island. Rep Hydrogr Oceanogr Res 46:87-91 (Japanese with English abstract)

Ishibashi J (2011) History of hydrothermal activities and associated biological communities in the Okinawa Trough, Cruise report of NT11-20. http://www.godac.jamstec.go.jp/darwin/cruise/ NATSUSHIMA/nt11-20/e

Ishibashi J, Oshiro M, Shimada K, Nozaki T, Yoshizumi R, Urabe T, Sato H (2013) Diversity of seafloor massive sulfide ores in the Okinawa Trough. In: Proceedings of Japan Geoscience Union Meeting 2013 (May 19-24, 2013, Chiba, Japan), BBG21-07

Provin C, Fukuba T, Okamura K, Fujii T (2013) An integrated microfluidic system for manganese anomaly detection based on chemiluminescence: description and practical use to discover hydrothermal plumes near the Okinawa Trough. IEEE J Ocean Eng 38:178-185

Takamasa A, Nakai S, Ishibashi J, Sato F, Toyoda S, Fujiwara T (2013) U-Th radioactive disequilibrium dating of hydrothermal vent of Okinawa and South Mariana Trough. In: Proceedings of Japan Geoscience Union Meeting 2013 (May 19-24, 2013, Chiba, Japan), BBG21-P06 